\title{
The Influence of Synthetic Amino Acid and Casein Hydrolysate on the Endogenous Production and Urinary Excretion of Acid in Total Intravenous Alimentation
}

\author{
James r. C. M. Chan ${ }^{[34]}$ \\ Department of Pediatrics, University of Southern California School of Medicine, and the Renal Division, \\ Childrens Hospital of Los Angeles, Los Angeles, California, USA
}

\section{Extract}

These investigations are designed to quantitate the acidogenic properties of several commonly used amino acid solutions. Infusion of amino acid solutions causes a rise in the sulfuric acid production $\left(\mathrm{H}_{\mathrm{SO}_{4}}^{+}\right)$to a rate of $26.8-93.1 \mu \mathrm{Eq} / \mathrm{min} / 1.73 \mathrm{~m}^{2}$, which is a 4- to 14-fold increase over the preinfusion rate of $6.6 \mu \mathrm{Eq} / \mathrm{min} / 1.73 \mathrm{~m}^{2}$. This is a reflection of the amount of sulfur-containing amino acids in the infusate; it is lower with the casein hydrolysate than with the synthetic amino acid. The increase in $\mathrm{H}_{\mathrm{SO}_{4}}^{+}$is also significantly less with the $2.13 \%$ solutions than with the $4.25 \%$ solutions.

The rate of organic acid production $\left(\mathrm{H}_{\mathrm{OA}}^{+}\right)$tends to be higher with the $4.25 \%$ casein hydrolysate $\left(48.1 \mu \mathrm{Eq} / \mathrm{min} / 1.73 \mathrm{~m}^{2}\right)$ than with both the $2.13 \%$ and the $4.25 \%$ synthetic amino acid solutions $\left(22.4-29.3 \mu \mathrm{Eq} / \mathrm{min} / 1.73 \mathrm{~m}^{2}\right)$. The latter value is not significantly different from the preinfusion rate of $\mathrm{H}_{\mathrm{OA}}^{+}\left(20.4 \mu \mathrm{Eq} / \mathrm{min} / 1.73 \mathrm{~m}^{2}\right)$. However, taken together, the results of these data are consistent with the view that the total amount of acid produced $\left(\mathrm{H}_{\mathrm{SO}_{4}}^{+}\right.$plus $\left.\mathrm{H}_{\mathrm{OA}}^{+}\right)$in association with infusion of the synthetic amino acid solutions is proportionately higher than that associated with infusion of the casein hydrolysate.

The absolute values for the acid excretion during amino acid infusions also show differences from the preinfusion state of $23.7 \mu \mathrm{Eq} / \mathrm{min} / 1.73 \mathrm{~m}^{2}$. The net acid excretion increased nearly four times during the infusion of the $4.25 \%$ synthetic amino acid and casein hydrolysate solutions. The net acid excretion is shown to be linearly correlated with the net acid production $(r=0.974)$. On the other hand, only $65 \%$ of net acid production is excreted as net acid by the kidneys, and the extracellular buffering can account for only a fraction of the difference between the net acid production and excretion.

These studies also provide the first conclusive evidence that the rate of endogenous acid production during glucose-water infusion is $26.9 \mu \mathrm{Eq} / \mathrm{min} / 1.73 \mathrm{~m}^{2}$ or $2-3$ $\mathrm{mEq} / \mathrm{kg} / 24 \mathrm{hr}$.

\section{Speculation}

The data presented suggest that the marked increase in endogenous acid production is related to the quantity and quality of amino acid-sulfur in the different types of 
infusates used in total intravenous alimentation and further suggest a signifcant nonextracellular buffering mechanism (possibly the skeletal system).

\section{Introduction}

In 1967, Dudrick, Wilmore, and Vars [9] demonstrated that normal growth and development could be maintained on total parenteral alimentation, utilizing a protein hydrolysate-dextrose water solution as the sole source of nitrogen, calories, and minerals. This procedure has now been used extensively in malnutrition and in a variety of conditions in which bypassing the gastrointestinal tract was required for long periods [10, $12,17,24]$. Septicemia and obstruction of major vessels were well known complications of intravenous alimentation $[12,17,24]$. But until recently, there have been virtually no studies on the biochemical and physiologic properties of these protein hydrolysates. Recently, Johnson et al. [16] reported the occurrence of hyperammonemia complicating parenteral nutrition in infants; Ghadimi et al. [13] confirmed the presence of inordinate amounts of ammonia in both fibrin hydrolysate [27] and casein hydrolysate [28], and Chan et al. [6] documented the high titratable acidity in casein hydrolysate as well as in synthetic amino acid [29] solutions.

These factors may have some bearing on the severe metabolic acidosis recently reported in small infants receiving parenteral alimentation $[5,15]$. The pathophysiology of this acidosis is complex. It involves the endogenous production of acid from the intermediary metabolism of the amino acids, and organic acids as well as the titratable acidity of the infusates. In addition, it involves the acid produced from the metabolic processes involved with the growth and breakdown of body tissues, as well as the elimination of these metabolic end products either as carbon dioxide through the lungs or as nonvolatile (fixed) acids through the kidneys. The renal excretion of acid is easily determined and consists of the sum of urinary titratable acid (TA) plus ammonium $\left(\mathrm{NH}_{4}{ }^{+}\right)$minus bicarbonate $\left(\mathrm{HCO}_{3}{ }^{-}\right)$[2l]. The quantitation of the net acidifying effects of the amino acid solutions is more difficult, on a conceptual as well as a technical basis. First, we are not dealing with a simple species of acid but with multiple sources of both external intake and endogenous production. Secondly, we are also dealing with internal metabolic processes, not easily accessible to external quantitative analysis. These conceptual and technical difficulties have proven to be a severe handi- cap in the study of acid-base metabolism in general, and in the study of the mechanism of the acidogenic properties of dietary components in particular. Recently, most of these difficulties have been alleviated by a series of elegant experiments, performed in the laboratories of Relmann, Lennon, and Lemann [14, 20, 22] and later extended by Kildeberg, Engels, and Winters for studies in rapidly growing premature infants [18]. Since the present study utilizes these new concepts to study endogenous acid production, it is necessary to present the following brief review on the general applicability and limitations of the net acid balance technique.

Net acid production is defined as the daily net gain of noncarbonic, nonmetabolizable acid from all extrarenal sources and consists of contributions from sulfuric acid production, organic anion excretion, and skeletal mineralization, each of which can be measured or approximated $[7,18]$. The first major component of endogenous acid consists of sulfuric acid production from metabolism of amino acids and is based on the oxidative pathway of amino acid-sulfur proposed by Lemann and Relman [19]. This is illustrated in Figure 1, where two hydrogen ions $\left(\mathrm{H}^{+}\right)$are produced as the consequence of biologic oxidation of methionine-sulfur to sulfate in an aqueous medium. Therefore, by measuring the urinary concentrations of sulfate, one could extrapolate the amount of hydrogen ions $\left(\mathrm{H}^{+}\right)$ stranded inside the body, obligating the kidneys as the only route of elimination $[7,18]$. The second major component of endogenous acid production is generated through the metabolism of neutral carbohydrate, fat, and protein and may be dissociated into organic

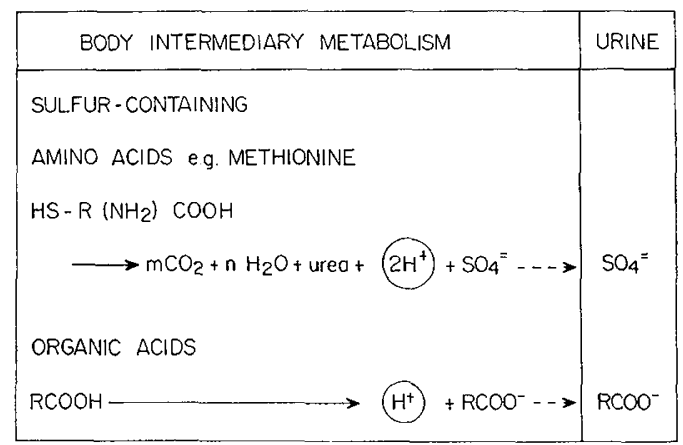

Fig. 1. The components of endogenous acid production from intermediary metabolism [18]. 
anions with the release of equivalent quantities of $\mathrm{H}^{+}$. In the event that these organic anions are completely metabolized to $\mathrm{CO}_{2}$ and $\mathrm{H}_{2} \mathrm{O}$, these $\mathrm{H}^{+}$are in effect "recaptured" and therefore do not affect the net acid balance. The organic acid which simply dissociates into organic anion and $\mathrm{H}^{+}$and which subsequently never is oxidized but is excreted in the urine as organic anions would leave behind an equivalent amount of $\mathrm{H}^{+}$stranded in the body fluids with the kidney as the only route of excretion. It is this quantity of organic acid which contributes to endogenous net acid production. Therefore, by measuring the urinary organic anions one can extrapolate the amount of $\mathrm{H}^{+}$produced as a result of this metabolic process (Fig. 1). These two processes constitute the major components of endogenous production of acid in the adult. In the rapidly growing premature infants there are complexities due to the release of $\mathrm{H}^{+}$through the deposition of hydroxyapatite in the growing bone [18] and in the absorption of potential base through the gastrointestinal tract $[7,18]$. In the present study the last two components of the net acid balance were not examined because the gastrointestinal tract was bypassed by the total intravenous alimentation. However, it must be pointed out that an error could occur because of stooling, but with the short period of study in our patients and no stooling in almost all cases, the error would be small. Another potential source of underestimation of the total endogenous acid production could be the exclusion of the hydrogen ions produced from new bone formation; however, since our balance collections lasted only a few days, it would certainly be invalid to consider any data from such short term calcium balances. It should be recognized that this criticism of short term balance studies applies only to cal- cium balances which require a long control period. It does not apply to the present study because the production of sulfuric acids and nonvolatile organic acids is very rapid and responsive to changes in cellular metabolism as well as the composition of the amino acid infusates and is not subject to the same inherent limitations of calcium balance studies.

Until recently, there have been few studies describing the relationship between infusions of synthetic amino acids and protein hydrolysate solutions and the development of severe metabolic acidosis $[9,10]$. At the present time there is no quantitative information on the components of endogenous production of acid from total intravenous alimentation. The present work was therefore designed to clarify this problem by applying the net acid balance technique to: $(1)$ isolate and compare the components of endogenous acid production; (2) delineate the differences and similarities of net acid production and excretion of different types of amino acid solutions; and (3) determine how the premature infants differ from the child with respect to quantity of net acid production and urinary excretion of acid.

\section{Material and Methods}

One 10-year-old child and four 1- to 2-week-old premature infants were studied (Table I). All patients were receiving either casein hydrolysate or synthetic amino acid (concentrations of either 4.25 or $2.13 \%$ ) therapeutically through a central venous catheter placed in the subclavian vein $[1,17]$. These solutions were supplemented with $20 \%$ glucose, potassium phosphate, and multiple vitamins to meet the minimal caloric, mineral, and vitamin requirements as previously reported $[1,5,6,17]$.

Table I. Clinical data on patients

\begin{tabular}{|c|c|c|c|c|c|c|}
\hline Patient & Age & Sex & $\begin{array}{c}\text { Weight, } \\
\text { kg }\end{array}$ & $\begin{array}{l}\text { Surface } \\
\text { area, } m^{2}\end{array}$ & Presenting disorder & Specific procedures \\
\hline$F M$ & $10 \mathrm{yrs}$ & $\mathrm{M}$ & 30.90 & 1.07 & $\begin{array}{l}\text { Perforated appendix with in- } \\
\text { traperitoneal abscesses and } \\
\text { intestinal fistulae }\end{array}$ & $\begin{array}{l}\text { Appendectomy, drainage of pelvic abscess, drain } \\
\text { age of subphrenic abscess, repair of entero- } \\
\text { cutaneous and coloenteric fistulae }\end{array}$ \\
\hline$M G$ & 2 wks & $\mathrm{M}$ & 2.55 & 0.19 & $\begin{array}{l}\text { Tracheoesophageal fistula, } \\
\text { imperforate anus, ileal } \\
\text { atresia, prematurity }\end{array}$ & $\begin{array}{l}\text { Gastrostomy, ligation of tracheoesophageal fis- } \\
\text { tula, laparotomy and lysis of adhesions for } \\
\text { jejunal volvulus, double barreled ileostomy, } \\
\text { sigmoid colostomy }\end{array}$ \\
\hline$R G$ & $1 \mathrm{wk}$ & $\mathrm{F}$ & 1.68 & 0.14 & $\begin{array}{l}\text { Duodenal atresia, esophageal } \\
\text { atresia, Down's syndrome }\end{array}$ & $\begin{array}{l}\text { Repairs of gastroschisis with silon sac technique, } \\
\text { ileostomy }\end{array}$ \\
\hline$A L$ & $2 \mathrm{wks}$ & $\mathrm{M}$ & 1.70 & 0.14 & $\begin{array}{l}\text { Tracheoesophageal fistula, } \\
\text { imperforate anus, ileal } \\
\text { atresia, prematurity }\end{array}$ & $\begin{array}{l}\text { Gastrostomy, ligation of tracheoesophageal fis- } \\
\text { tula, laparotomy and lysis of adhesions for } \\
\text { jejunal volvulus, double barreled ileostomy, } \\
\text { sigmoid colostomy }\end{array}$ \\
\hline
\end{tabular}


Table II. Representative study of 10 -year-old male patient FM (weight, $30.9 \mathrm{~kg}$; surface area, $\left.1.07 \mathrm{~m}^{2}\right)^{1}$

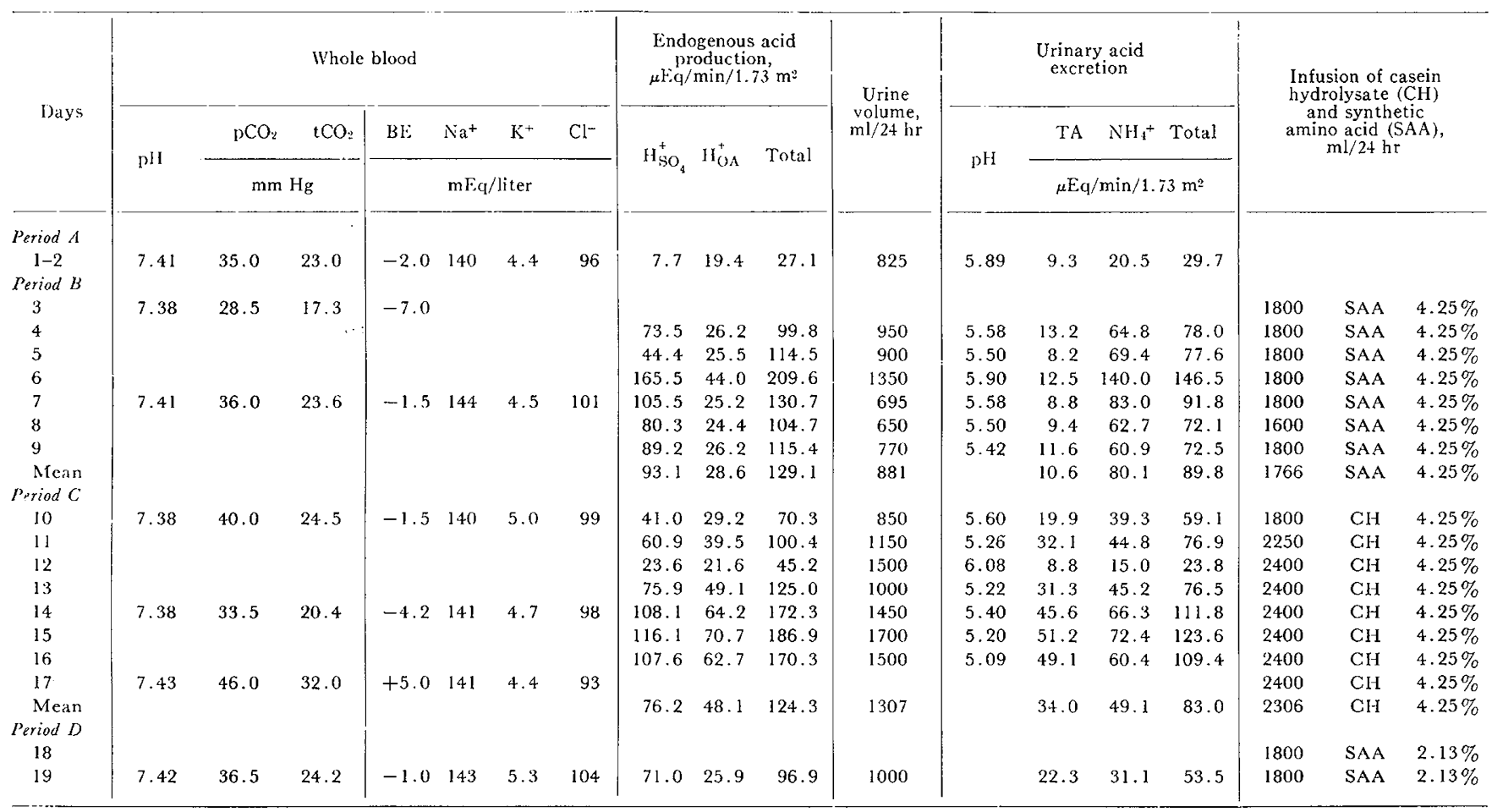

$1 \mathrm{H}_{\mathrm{SO}_{4}}^{+}$: sulfuric acid production; $\mathrm{H}_{\mathrm{OA}}^{+}$: organic acid production; TA : titratable acid; $\mathrm{NH}_{4}{ }^{+}$: ammonium.

In order to quantitate and compare the endogenous production of acid unaugmented by the exogenous amino acid infusions, four of the patients were sustained on $20 \%$ glucose-water intravenously for 2 days without the addition of casein hydrolysate or synthetic amino acid solutions but with the same supplements of mineral and vitamins [6]. During this period the caloric intake was $80 \mathrm{kcal} / \mathrm{kg} / 24 \mathrm{hr}$ and should be sufficient to prevent any rise in endogenous acid production secondary to increased catabolism.

Twenty-four-hour urine specimens were collected for 2 to 19 consecutive days and frozen until measured. The volumes of casein hydrolysate or synthetic amino acid solutions infused were recorded and accurately timed. Blood samples were taken every 2 nd to 5 th day for determinations of acid-base status by the equilibration method of Astrup [2]; sodium and potassium by flame photometry; chloride by the Buchler-Cotlove technique [8]. Urinary sulfate was determined by the method of Yatzidis et al. [26]. Urinary organic anion concentration and urinary net acid excretion (TA + $\mathrm{NH}_{4}{ }^{+}-\mathrm{HCO}_{3}{ }^{-}$) were determined by previously described methods from this laboratory $[3,4]$.

\section{Results}

Complete analytical data from one subject who received both concentrations of synthetic amino acid solutions (4.25 and $2.13 \%$ ) as well as casein hydrolysate (4.25\%) are shown in Table II. Days 3, 17, and 18 were equilibration periods, and no urine collection was obtained. The four collection periods correspond to $(A)$ no infusion; $(B) 4.25 \%$ synthetic amino acid infusion; $(C) 4.25 \%$ casein hydrolysate infusion; and $(D) 2.13 \%$ synthetic amino acid infusion.

Table III presents the mean endogenous production of acid for subjects receiving the different types of synthetic amino acid or casein hydrolysate solution and compares this with the mean endogenous acid production during periods of no amino acid infusion. In addition, the urinary excretion of acid is shown. Each component of acid production and excretion is also presented.

Figure 2 compares the net acid production with the net acid excretion, showing a linear relationship between them $(r=0.974)$.

Table IV compares the mean values of net acid production and excretion in the subjects during the con- 
Table III. Mean values of components of endogenous acid production and renal acid excretion during steady acid-base status in patients on synthetic amino acid (SAA) or casein hydrolysate $(\mathrm{CH})$ alimentation and off infusion ${ }^{1}$

\begin{tabular}{|c|c|c|c|c|c|c|c|c|c|c|c|c|c|c|}
\hline \multirow{2}{*}{ Subject } & \multirow{2}{*}{ Age } & \multirow{2}{*}{$\begin{array}{c}\text { Days } \\
\text { of } \\
\text { study }\end{array}$} & \multirow{2}{*}{$\begin{array}{c}\text { Surface } \\
\text { area, } \\
\mathrm{m}^{2}\end{array}$} & \multicolumn{4}{|c|}{ Endogenous acid production ${ }^{1}$} & \multirow{2}{*}{$\begin{array}{c}\text { Urine } \\
\text { volume, } \\
\mathrm{ml} / 24 \mathrm{hr}\end{array}$} & \multicolumn{3}{|c|}{$\begin{array}{l}\text { Urinary acid excretion, } \\
\mu \mathrm{Eq} / \min / 1.73 \mathrm{~m}^{2}\end{array}$} & \multirow{2}{*}{\multicolumn{3}{|c|}{ Infusion, $\mathrm{ml} / 24 \mathrm{hr}$}} \\
\hline & & & & & $/ \mathrm{min} / 1$ & & & & TA & $\mathrm{NH}_{4}{ }^{+}$ & Total & & & \\
\hline \multicolumn{15}{|l|}{ Group I } \\
\hline$F M$ & 10 yrs & 2 & 1.07 & 7.7 & 19.4 & 27.1 & 28 & 825 & 9.3 & 20.5 & 29.7 & \multicolumn{3}{|c|}{ No infusion } \\
\hline$M G$ & 2 wks & 2 & 0.19 & 13.1 & 13.6 & 26.6 & 49 & 143 & 2.4 & 21.8 & 24.2 & \multicolumn{3}{|c|}{ No infusion } \\
\hline Average & & & & 6.6 & 20.4 & 26.9 & 25 & & 4.1 & 19.7 & 23.7 & & & \\
\hline \multicolumn{15}{|l|}{ Group II } \\
\hline$F M$ & 10 yrs & 6 & 1.07 & 93.1 & 28.6 & 129.1 & 72 & 881 & 10.6 & 80.1 & 89.8 & 1766 & $\mathrm{~S} \wedge \mathrm{A}$ & $4.25 \%$ \\
\hline$M G$ & $2 \mathrm{wks}$ & 2 & 0.19 & 80.6 & 24.7 & 105.3 & 77 & 220 & 8.5 & 73.0 & 81.5 & 360 & SAA & $4.25 \%$ \\
\hline \multicolumn{15}{|l|}{ Group III } \\
\hline$F M$ & $10 \mathrm{yrs}$ & 7 & 1.07 & 76.2 & 48.1 & 124.3 & 61 & 1307 & 34.0 & 49.1 & 83.0 & 2306 & $\mathrm{CH}$ & $4.25 \%$ \\
\hline \multicolumn{15}{|l|}{ Group V } \\
\hline$R G$ & $1 \mathrm{wk}$ & 3 & 0.14 & 29.4 & 28.9 & 58.3 & 50 & 197 & 4.4 & 18.7 & 23.1 & 265 & $\mathrm{CH}$ & $2.13 \%$ \\
\hline
\end{tabular}

${ }^{1} \mathrm{H}_{\mathrm{SO}_{4}}^{+}$, sulfuric acid production; $\mathrm{H}_{\mathrm{OA}}^{+}$, organic acid production; $\mathrm{TA}$, titratable acid; $\mathrm{NH}_{4}^{+}$, ammonium.

trol period with only glucose-water administration (group I) and during the infusions of the two different concentrations (4.25 and $2.13 \%$ ) of synthetic amino acid and casein hydrolysate solutions (groups $I I-V)$. The net acid excretion accounts for only $40-88 \%$ (average $65 \%$ ) of the net acid production.

\section{Discussion}

The experimental data presented above indicate that in the absence of amino acid infusion, the endogenous acid production in premature infants and the child varied from 24.5 to $29.7 \mu \mathrm{Eq} / \mathrm{min} / 1.73 \mathrm{~m}^{2}$ with a mean of $26.9 \mu \mathrm{Eq} / \mathrm{min} / 1.73 \mathrm{~m}^{2}$ (Table III, group $\mathrm{l}$ ). This confirmed our earlier assumption [5] that the rate of endogenous acid production in a steady state for infants and children was $29 \mu \mathrm{Eq} / \mathrm{min} / 1.73 \mathrm{~m}^{2}$. These data substantiated the previous theoretical assumption $[15,23]$ that the endogenous acid production in infants and children was about $2-3 \mathrm{mEq} / \mathrm{kg} / 24 \mathrm{hr}$. There were no differences between the rates of endogenous acid production in premature infants and the child on a body surface basis, although on a weight basis it was less in the child than in the infant (1.4 versus 2.8 $\mathrm{mEq} / \mathrm{kg} / 24 \mathrm{hr}$ [30]. It is, however, difficult to draw general conclusions for children of his age group from this single observation.

Analysis of the urinary acid excretion in the prein-

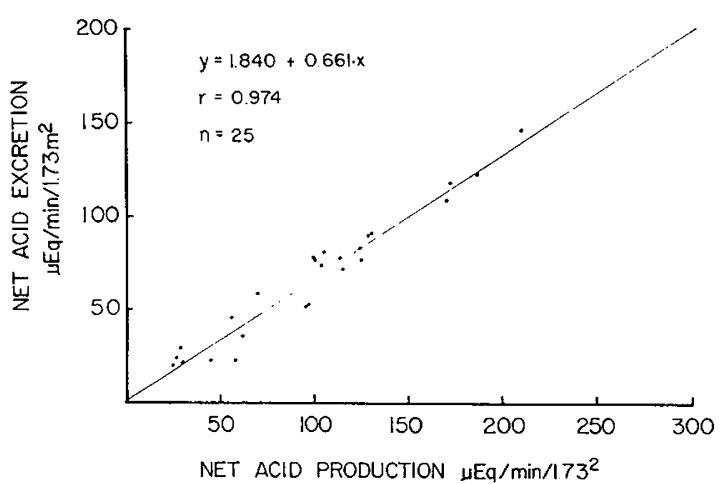

Fig. 2. Regression of net acid excretion (NAE) on net acid production (NAP), by the method of least squares: NAE $=1.840+$ $0.661 \cdot \mathrm{NAP} ; S_{y . x} 8.064 ; S D_{b} 0.031$.

Table IV. Percentage of net acid production excreted in the urine by subjects on synthetic amino acid (SAA) and casein hydrolysate $(\mathrm{CH})$ of different concentrations

\begin{tabular}{|c|c|c|c|c|}
\hline \multirow{2}{*}{\multicolumn{2}{|c|}{ Group }} & $\begin{array}{l}\text { Net acid } \\
\text { production } \\
(\text { NAP })\end{array}$ & $\begin{array}{l}\text { Net acid } \\
\text { excretion } \\
\text { (NAE) }\end{array}$ & \multirow[t]{2}{*}{$\frac{\mathrm{NAE}}{\mathrm{NAP}} \times 100, \%$} \\
\hline & & \multicolumn{2}{|c|}{$\mu \mathrm{Eq} / \mathrm{min} / 1.73 \mathrm{~m}^{2}$} & \\
\hline$I$. & No infusion & 26.9 & 23.7 & 88 \\
\hline$I I$. & $\mathrm{SAA}, 4.25 \%$ & 132.2 & 85.7 & 65 \\
\hline$I I I$. & $\mathrm{CH}, \quad 4.25 \%$ & 124.3 & 83.0 & 67 \\
\hline IV. & S.1. $2.13 \%$ & 71.7 & 45.1 & 63 \\
\hline \multirow{2}{*}{\multicolumn{2}{|c|}{$\begin{array}{l}V . \mathrm{CH}, 2.13 \% \\
\text { Average }\end{array}$}} & 58.3 & 23.1 & 40 \\
\hline & & & & 65 \\
\hline
\end{tabular}


fusion period (Table III, group $I$ ) showed that the net acid excretion varied between 19.7 and $29.7 \mu \mathrm{Eq} / \mathrm{min} /$ $1.73 \mathrm{~m}^{2}$, with a mean of $23.7 \mu \mathrm{Eq} / \mathrm{min} / 1.73 \mathrm{~m}^{2}$, which closely approximated the endogenous acid production. This zero net acid balance was reflected in the normal blood acid-base status as illustrated by patient $F M$ in Table II (period $A$ ).

Sulfuric acid production $\left(\mathrm{H}_{\mathrm{SO}_{4}}^{+}\right)$increased 4 to 14 times after the infusions of both synthetic amino acid and casein hydrolysate. A more than 10 -fold increase (Table III, groups $I I$ and $I I I$ ) occurred with the $4.25 \%$ concentration of either casein hydrolysate or synthetic amino acid. A mean increment of fourfold increase was obtained with the $2.13 \%$ concentration of either solution (Table III, groups $I V$ and $V$ ). This probably reflected the larger amount of sulfur-containing amino acids at the $4.25 \%$ concentration. The $\mathrm{H}_{\mathrm{SO}_{4}}^{+}$with the casein hydrolysate tended to be lower than that procluced by synthetic amino acid. In contrast, net organic acid production $\left(\mathrm{H}_{\mathrm{OA}}^{+}\right)$with the $4.25 \%$ casein hydrolysate (group III) tended to be higher than that produced by the $4.25 \%$ synthetic amino acid (group II). This probably reflected the quality and quantity of protein in the different amino acid solutions although the total amount of net acid generated was approximately identical for both.

It was of interest to note that in the preinfusion period (Table III, group $I$ ) the sulfuric acid production $\left(\mathrm{H}_{\mathrm{SO}_{4}}^{+}\right)$accounted for $10-49 \%$ of the total acid production, with an average of $25 \%$. With the infusion of $4.25 \%$ synthetic amino acid (Table III, group $I I)$, sulfuric acid production varied between 72 and $77 \%$ of the total acid production, and with the $4.25 \%$ casein hydrolysate it was $61 \%$. Analysis of the data from the subjects receiving $2.13 \%$ solutions also showed similar differences.

These data indicate that the amount of acid produced when infusing synthetic amino acid solutions was proportionately higher than with casein hydrolysate. This was probably a reflection of the high concentration of sulfur-containing amino acids (e.g., methionine, casein, etc.) in the synthetic amino acid solutions.

The absolute values for the acid excretion during amino acid infusion also differed from the preinfusion state. The total urinary acid excretion for the four subjects during the preinfusion period in group $I$ (Table III) varied between 19.7 and $29.7 \mu \mathrm{Eq} / \mathrm{min} /$ $1.73 \mathrm{~m}^{2}$ (mean $23.7 \mu \mathrm{Eq} / \mathrm{min} / 1.73 \mathrm{~m}^{2}$ ). This net acid excretion increased approximately fourfold in groups $I I$ and $I I I$ during the period of $4.25 \%$ synthetic amino acid and casein hydrolysate infusions. Such a marked increase did not result from infusions of the $2.13 \%$ solutions.

A linear relationship between the net acid excretion and the net acid production was depicted in Figure 2 (correlation coefficient $r=0.974$ ). However, the net acidifying effect of the alimentation solutions cannot be completely accounted for by the increased net acid excretion. Table IV showed that the kidneys excreted only $65 \%$ of the net acid production. This suggested either that the other $35 \%$ of released acid was partially neutralized by extracellular buffers or that considerable nonextracellular buffers were involved. These data supported our previous observation that nonextracellular buffers during development or recovery from metabolic acidosis were significant [25]. The decreased serum bicarbonate and base excess could account for only a fraction of the difference between the net acid production and excretion (Table II).

In all groups (Table III), the urinary ammonium $\left(\mathrm{NH}_{4}{ }^{+}\right)$excretion was the largest single component, and there seemed to be little difference in the response of the infants compared with the child $(F M)$. Of particular interest was the relatively small response in urinary titratable acidity (TA) in the infants compared with that of the child $(F M)$. This was contrary to the pattern of hydrogen ion excretion in normal infants, where there was a higher rate of TA excretion and a lower rate of excretion of $\mathrm{NH}_{4}+$ [11]. A possible explanation of these differences was suggested by the low phosphate excretion secondary to the relatively small phosphate supplements in the amino acid solutions [6]. A previous study from this laboratory had shown that the total net acid excretion $\left(\mathrm{TA}+\mathrm{NH}_{4}+\right.$ $-\mathrm{HCO}_{3}{ }^{-}$) in these infants was not impaired. The higher rate of $\mathrm{NH}_{4}+$ excretion adequately compensated for the lower rate of TA excretion [5].

In view of the complexities presented above on the acidogenic effects of amino acid solutions, a previous report on the high titratable acidity of the casein hydrolysate and synthetic amino acid solutions $[5,6]$ as an explanation for the pathophysiology of the severe metabolic acidosis encountered in total intravenous alimentation may be too simplistic. The high titratable acidity of the infusates may represent volatile acid, metabolizable to carbon dioxide and eliminated in the lungs without obligating renal excretion; conversely, prolonged administration of casein hydrolysate and synthetic amino acid may present such an excessive exogenous acid intake as to overwhelm the extracellular buffering capacity and renal acid excretion so that 
metabolic acidosis develops [5, 15]. Further studies are necessary to clarify this point.

The present study gives further experimental confirmation of our previous recommendation for the use of the $2.13 \%$ solutions instead of the $4.25 \%$ solutions [5] because the acidifying effects are shown to be significantly less with the former (Table III). The daily minimal amino acid requirements are still fulfilled at the lower concentration.

\section{Summary}

The acidogenic potential of the commonly used casein hydrolysate and synthetic amino acid solutions were tested by independent measurements of the urinary sulfate and organic anions to assess the quality and quantity of endogenous sulfuric acid and organic acid production. In all five patients studied, both solutions were found to be highly acidogenic, resulting in total endogenous acid production $(58.3-129.1 \mu \mathrm{Eq} / \mathrm{min} / 1.73$ $\left.\mathrm{m}^{2}\right)$ several times higher than that during the control periods $\left(26.9 \mu \mathrm{Eq} / \mathrm{min} / 1.73 \mathrm{~m}^{2}\right)$.

It was also shown that sulfuric acid production is proportionately higher with synthetic amino acid infusions, which seems likely to be related to the higher quantity of amino acid-sulfur. The increased acid production correlates well with kidneys' response to increased net acid excretion $(r=0.974)$. However, the data indicate that the renal net acid excretion could account for $65 \%$ of the net acid production and the extracellular buffers could account for only a fraction of the other $35 \%$, thereby suggesting a heretofore unrecognized mechanism of nonextracellular buffering.

The net effect of this imbalance of endogenous production over renal excretion of acid results in accumulation of acid, which probably contributes to the development of metabolic acidosis seen in the patients receiving total intravenous alimentation.

\section{References and Notes}

1. Asch, M. J., Shaw, K. N. F., AND Hays, D. M.: Evaluation of different nitrogen sources in high caloric parenteral therapy. J. Pediat. Surg., 7: 213 (1972).

2. Astrup, P., Jorgensen, K., Siggard-Andersen, A., and Engel, K.: The acid-base metabolism. A new approach. Lancet, $i$ : 1035 (1960).

3. Chan, J. C. M.: The determination of urinary titratable acid and ammonium-evaluation of freezing as a method of preservation. Clin. Biochem., 5: 94 (1972).

4. Chan, J. C. M.: Urinary organic anions-clinical significance and a method for determination. Clin. Biochem. (in press).

5. Chan, J. C. M., Asch, M. J., Lin, S., And Hays, D. M.: Mechanism of acidosis in hyperalimentation with casein hydroly- sate and synthetic amino acid infusates. J. Amer. Med. Ass., 220: 1700 (1972).

6. Chan, J. C. M., Malekzadeh, M., and Hurley, J.: pH and titratable acidity of amino acid mixtures used in hyperalimentation. J. Amer. Med. Ass., 220: 1119 (1972).

7. Chan, J. C., Kirdeberg, P., Engel, K., and Winters, R. W.: Net acid balance in growing infants (Abstract). Pediat. Res., 4: 447 (1970).

8. Cotlove, E.: Chloride standard methods. In: D. Seligson: Standard Methods of Clinical Chemistry, Vol. 3, p. 81. (Academic Press, New York, 1961).

9. Dudrick, S. J., Wilmore, D. W., and Vars, H. M.: Long-term parenteral nutrition with growth in puppies and positive nitrogen balance in patients. Surg. Forum, 18: 356 (1967).

10. Dudrick, S. J., Wilmore, D. W., Vars, H. M., and Rhoads, J. E.: Long-term total parenteral nutrition with growth, development and positive nitrogen balance. Surgery, 64: 134 (1968).

11. Edelmann, C. M., Rodriguez-Soriano, J., Borchis, H., GrushKIN, A. B., AND AcostA, M. I.: Renal bicarbonate reabsorption and hydrogen ion excretion in normal infants. J. Clin. Invest., 46: 1309 (196\%).

12. Filler, R. M., Eraklis, A. J., Rubin, V. G., and Das, J. B.: Long-term total parenteral nutrition in infants. New Engl. J. Med., 281: 589 (1969).

13. Ghadimi, H., Abaci, F., Kuman, S., and Rathi, M.: Biochemical aspects of intravenous alimentation. Pediatrics, 48 : 955 (1971).

14. Goodman, A. D., Lemann, J., Jr., Lennon, E. J., and Relman, A. S.: Production, excretion and net balance of fixed acid in patients with renal acidosis. J. Clin. Invest., 44: 495 (1965).

15. Heird, W. W., Dell, R. B., Grebin, B., and Winters, R. W.: Acidosis in infants alimented parenterally with synthetic L-amino acid mixtures (Abstract). In: Proceedings of the 41 st Annual Meeting, Society for Pediatric Research, Atlantic City, N. J., April 28-May 1, 1971.

16. Johnson, J., Albritton, W. L., and Sunshine, P.: Hyperammonemia complicating parenteral nutrition in infants (Abstract). Pediat. Res., 5: 414 (1971).

17. Kaplan, M. S., Mares, A., Quintana, P., Strauss, J., HuXtable, R. F., Brennan, P., and Hays, D. M.: High caloric glucose-nitrogen infusions in post-operative management of neonatal infants. Arch. Surg., 99: 567 (1969).

18. Kildeberg, P., Engels, K., and Winters, R. W.: Balance of net acid in growing infants-endogenous and transintestinal aspects. Acta Paediat. Scand., 58: 32 I (1969).

19. Lemann, J., JR., and Relman, A. S.: The relation of sulfur mctabolism to acid-base balance and electrolyte excretion: the effects of ob-methionine in normal man. J. Clin. Invest., 38: 2215 (1959).

20. Lennon, E. J., Lemann, J., JR., and Litzow, J. R.: The effects of diet and stool composition on the net external acid balance of normal subjects. J. Clin. Invest., 45: 1601 (1966).

21. Prrts, R. F.: Physiology of the Kidney and Body Fluids. (Year Book Medical Publishers, Chicago, 1968).

22. Relman, A. S., Lennon, E. J., and Lemann, J., JR.: Endogenous production of fixed acid and the measurements of the net balance of acid in normal subjects. J. Clin. Invest., 40: 1621 (1961).

23. Rodriguez-Soriano, J.: The renal regulation of acid-base balance and the disturbances noted in renal tubular acidosis. Pediat. Clin. N. Amer., 18: 529 (1971). 
24. Sherman, J. O., Egan, T., and Macalad, F. V.: Parenteral hyperalimentation-a useful surgical adjunct. Surg. Clin. N. Amer., 51: 37 (1971).

25. Winters, R. W., Chan, J. C., Klenk, E. L., Williams, G. S., AND Dell, R. B.: Net acid balance (NAB) in metabolic acidosis (Abstract). Pediat. Res., 5: 395 (197I).

26. Yatzidrs, H., Orepoulous, D., Symvoulidis, A., TriantaphylLIDis, D., AND Yannrtsrotis, A.: Une methode simple pour de la dosage des sulfates dans le serum et l'urine. Rev. Fr. Etud. Clin. Biol., 9: 126 (1964).

27. Aminosol, Abbott Laboratories, Chicago, Ill.

28. Hyprotigen, McGaw Laboratories, Glendale, Calif.

29. FreAmine, McGaw Laboratories, Glendale, Calif.

30. For example, in the 10-year-old child $(F M)$ who weighed $30.9 \mathrm{~kg}$ (surface area, $1.07 \mathrm{~m}^{2}$ ), the endogenous acid production of $27.1 \mu \mathrm{Eq} / \mathrm{min} / 1.73 \mathrm{~m}^{2}$ (Table III, group $I$ ) is equivalent to $1.4 \mathrm{mEq} / \mathrm{kg} / 24 \mathrm{hr}$, i.e., $\left[27.1 \mu \mathrm{Eq} / \mathrm{min} / 1.73 \mathrm{~m}^{2} \times(1440\right.$ $\left.\min / 1000) \times 1.07 \mathrm{~m}^{2}\right] \div 30.9 \mathrm{~kg}=1.4 \mathrm{mEq} / \mathrm{kg} / 24 \mathrm{hr}$. Similarly for the 2-week-old infant $(M G)$ with body weight of $2.59 \mathrm{~kg}$ (surface area, $0.19 \mathrm{~m}^{2}$ ), the endogenous acid produc- tion at a rate of $26.6 \mu \mathrm{Eq} / \mathrm{min} / 1.73 \mathrm{~m}^{2}$ is equivalent to 2.8 $\mathrm{mEq} / \mathrm{kg} / 24 \mathrm{hr}$.

31. This study was performed within the spirit of the Declaration of Helsinki.

32. It is a pleasure to acknowledge the help from Daniel $\mathbf{M}$. Hays, M.D., and Morris J. Asch, M.D., for clinical materials; Peter Dukes, Ph.D., for statistical advice; Jeane Gullihur, B.A., Rebecca Ma, B.A., Mona Donckerwolcke, and Stanley Lin for expert technical assistance; and especially George Domnell, M.D., Richard N. Fine, M.D., Fred Smith, M.D., and Marion Wang, Ph.D., for constructive criticism and encouragement.

33. Supported in part by a grant from the Southern California Kidney Foundation and by Grant no. RR-86 from the General Clinical Research Centers Program of the Division of Research Resources, National Institutes of Health.

34. Requests for reprints should be addressed to: JAMES C. M. Chan, M.D., Childrens Hospital of Los Angeles, P. O. Box 54700 Terminal Annex, Los Angeles, Calif. 90054 (USA).

35. Accepted for publication June 13, 1972. 